\title{
ASSESSING THE IMPACT OF CORONA VIRUS (COVID-19) ON TOURISM AND HOSPITALITY INDUSTRY IN INDIA- A PERSPECTIVE STUDY
}

\author{
Dr. Jasveen Kaur ${ }^{1}$, Jobanjeet Kaur ${ }^{2 *}$ \\ ${ }^{1}$ Senior Faculty and Former Chairperson-Head, \\ University Business School (UBS), Guru Nanak Dev University (GNDU), \\ Amritsar, Punjab, India. \\ ${ }^{2}$ Research Fellow, University Business School (UBS), \\ Guru Nanak Dev University (GNDU), Amritsar, Punjab, India \\ *Corresponding Author
}

\begin{abstract}
PURPOSE: This study's primary objective is to assess the corona virus's impact on India's tourism and hospitality industry and its segments regarding revenue and job losses. Further, there is a need for fundamental control strategies and a crisis management plan.

RESEARCH METHODOLOGY: Systematic literature review, secondary data, expert opinion surveys, and qualitative methods are the basis.

OBSERVATIONS AND DISCUSSION: The Indian government and tourism and hospitality marketers took numerous initiatives to mitigate losses and ensure people's safety. Post-COVID-19 is the new normal, where changes in technology and tourists' behavior are expected. Artificial intelligence, automated and digital systems are required to maintain the 'No Touch' policy. Therefore, tourism and hospitality marketers should consider the challenges addressed by tourism operators, hotel managers, and airline employees. This industry will take few years to recover to its standards in response to the restructuring, rightsizing, and downsizing approaches.

MANAGERIAL AND RESEARCH IMPLICATIONS: COVID model and control strategies are given as crisis management plans.

Key Words: Tourism \& Hospitality Industry, India, Corona virus-Covid-19, GDP, Control strategies, COVID model

Cite this Article: Jasveen Kaur and Jobanjeet Kaur, Assessing the Impact of Corona Virus (Covid-19) on Tourism and Hospitality Industry in India - A Perspective Study, International Journal of Management, 11(12), 2020, pp 3496-3511.

https://iaeme.com/Home/issue/IJM?Volume $=11 \&$ Issue $=12$
\end{abstract}


Assessing the Impact of Corona Virus (Covid-19) on Tourism and Hospitality Industry in India A Perspective Study

\section{INTRODUCTION}

People had been excited about celebrating the start of the new decade i.e., new year, 2020, unaware that this year had a virus in store for them. A virus: Coronavirus, officially known as COVID-19, clutched the world in its claws in just a couple of months. India had its first case of coronavirus on January 30, 2020, and eventually, the Ministry of Health and Family Welfare (MOHFW) corroborated 216,919 cases in the country by June 4, 2020 (MoHFW| Home 2020). The country had the most significant confirmed cases of the coronavirus in Asia, with a total of two lakhs on June 3, 2020 (Sharma, 2020). Eventually, the government of India declared a lockdown in the country and the temporary shutdown of many commercial establishments and educational institutions (Niewiadomski, 2020). For this reason, around 14 crore people lost their jobs in India (Vyas, 2020). The Centre for Monitoring Indian Economy (CMIE) reported that within 30 days after announcing the country's lockdown, the unemployment rate increased from 19 percent to 26 percent (Vyas, 2020). Therefore, around 53\% of Indian businesses had a specific amount of effect on their activities in March 2020 due to COVID-19, as per the survey of the Federation of Indian Chambers of Commerce \& Industry (FICCI) (Mukherji, 2020).

\subsection{The Pre-Pandemic Stagnation in the Economy of India}

The COVID-19 pandemic became the most economically exorbitant pandemic in history. World trade had already slowed down before the outbreak due to the US-China tension by around 1.5 percent. But, coronavirus and later globally synchronized lockdown resulted in unprecedented economic downfalls. The Organization for Economic Co-operation and Development (OECD) estimated that large-scale shutdowns would bring a fall of 20-25 percent in GDP for every month after lockdown. This meant that a three-month shutdown would reduce global annual GDP by 5-7 percent. The estimated impact of the coronavirus on global GDP growth for 2020 was around 4 percent, with a further chance to decrease.

India had no exemption with a decrease of GDP to 2 percent in 2020. India's growth rate had fallen from $8.0 \%$ in Q4 FY18 to $4.5 \%$ in Q2 FY20 (Bhattacharya \& Mathew, 2019). In January 2020, a long time before India's lockdown, the International Monetary Fund (IMF) had reduced India's GDP estimates for 2020 (Rajan \& Gopalan, 2020 and Bhattacharya, 2019). The reasons for this reduction in India's GDP rate have been the demonetization of the Indian banknote (2016) and the Goods and Services Tax (GST) enactment (2017), both of which caused severe consecutive disruptions in the Indian economy (Sastry, 2019).Various other financial emergencies in the country, viz, the Infrastructure Leasing \& Financial Services crisis and the failure of the 'Make in India' scheme, brought a deceleration in the Indian economy (Rajan \& Gopalan, 2020).

The Indian tourism and hospitality industry has been one of the industries that have been affected by this pandemic. The reason has been that this industry offers perishable goods to its customers in the form of services, which can't store for the future. The tourism and hospitality industry offers direct or indirect employment to millions of people, but due to this pandemic, many jobs have been at the edge (Kumar, 2020 \& Radhakrishnan, 2020). According to the World Travel and Tourism Council (WTTC), more than 100 million jobs have been lost globally as a result of the abrupt halt in travel. And, the Indian tourism and hospitality industry has faced a loss of 38 million jobs (Sanyal, 2020). Thus, the COVID-19 has been the worst crisis that has ever hit the tourism and hospitality industry in India. 


\section{LITERATURE REVIEW}

Various national and international research papers have been reviewed, and some of the relevant literature reviews have been presented in Table 2.1:

Table 2.1

\begin{tabular}{|c|c|c|c|c|c|}
\hline $\begin{array}{l}\text { Sr. } \\
\text { no. }\end{array}$ & Author/Year & Country & $\begin{array}{c}\text { Objective/ } \\
\text { Focus }\end{array}$ & Findings & Discussion \\
\hline 1. & Agarwal (2020) & India & $\begin{array}{l}\text { A comparative } \\
\text { analysis has been } \\
\text { done in this study } \\
\text { concerning the } \\
\text { coronavirus } \\
\text { situation during the } \\
\text { lockdown and initial } \\
68 \text { days of } \\
\text { unlocking phase in } \\
\text { India. } \\
\end{array}$ & $\begin{array}{l}\text { Due to improper } \\
\text { implementation of the } \\
\text { testing protocol in India, } \\
\text { the test positivity rate, and } \\
\text { gradual increase in testing } \\
\text { rate have multiplied in the } \\
\text { unlock phase. }\end{array}$ & $\begin{array}{l}\text { The use of the rapid test as an } \\
\text { alternative to the RT-PCR test } \\
\text { brought under assessment of } \\
\text { the actual cases. Therefore, } \\
\text { necessary measures should be } \\
\text { taken to amend this situation; } \\
\text { otherwise, data wouldn't reflect } \\
\text { the actual numbers. }\end{array}$ \\
\hline 2. & Dewan (2020) & Malaysia & $\begin{array}{l}\text { The economic } \\
\text { impact of the } \\
\text { coronavirus on the } \\
\text { hospitality industry } \\
\text { of Malaysia has } \\
\text { been the focus of } \\
\text { this study. }\end{array}$ & $\begin{array}{l}\text { The feasibility and } \\
\text { applicability of the } \\
\text { Malaysian model have } \\
\text { been checked on the Indian } \\
\text { hospitality and tourism } \\
\text { market. }\end{array}$ & $\begin{array}{l}\text { This study focused on the short- } \\
\text { term, medium-term, and long- } \\
\text { term impact of this global crisis } \\
\text { on the hospitality industry. } \\
\text { Further, solutions have been } \\
\text { provided by the Malaysian } \\
\text { Association of Hotels (MAH). }\end{array}$ \\
\hline 3. & Ghosh (2020) & India & $\begin{array}{l}\text { The strategies to } \\
\text { overcome the } \\
\text { problems faced by } \\
\text { the Indian travel } \\
\text { industry due to } \\
\text { COVID-19 have } \\
\text { been addressed. }\end{array}$ & $\begin{array}{l}\text { The study has highlighted } \\
\text { the effect of this pandemic } \\
\text { on the travel industry at the } \\
\text { national and international } \\
\text { levels. Additionally, it } \\
\text { addressed the stakeholders' } \\
\text { approach and } \\
\text { recommended a tourism } \\
\text { policy. }\end{array}$ & $\begin{array}{l}\text { This pandemic has created an } \\
\text { emergency for the travel } \\
\text { industry, which has put a global } \\
\text { halt to economic activities as } \\
\text { well as the movement of } \\
\text { people. }\end{array}$ \\
\hline 4. & Golechha (2020) & India & $\begin{array}{l}\text { The goal of this } \\
\text { research has been to } \\
\text { develop community- } \\
\text { based capacity to } \\
\text { deal with local } \\
\text { issues. }\end{array}$ & $\begin{array}{l}\text { A systematic approach to } \\
\text { rescue people from this } \\
\text { situation of panic, fear, and } \\
\text { depression has been } \\
\text { followed in the country. }\end{array}$ & $\begin{array}{l}\text { The government should come } \\
\text { forward to convert this situation } \\
\text { of threat into a situation of } \\
\text { opportunity for the industry of } \\
\text { India. }\end{array}$ \\
\hline 5. & $\begin{array}{l}\text { Gossling et al. } \\
\text { (2020) }\end{array}$ & NA & $\begin{array}{l}\text { The focus of this } \\
\text { study has been to } \\
\text { explore the change } \\
\text { that the pandemic } \\
\text { has brought to } \\
\text { tourism and the } \\
\text { economy. }\end{array}$ & $\begin{array}{l}\text { A comparison of other } \\
\text { forms of the global crisis } \\
\text { has been made with the } \\
\text { COVID-19 to see its } \\
\text { devastating impact. }\end{array}$ & $\begin{array}{l}\text { Global travel restrictions have } \\
\text { caused severe disruption to } \\
\text { tourism. }\end{array}$ \\
\hline 6. & Hao et al. (2020) & China & $\begin{array}{l}\text { China's hotel } \\
\text { industry has been } \\
\text { surveyed to explore } \\
\text { the general effects } \\
\text { of the coronavirus. }\end{array}$ & $\begin{array}{l}\text { The counter pandemic } \\
\text { techniques and standards } \\
\text { have been introduced as a } \\
\text { management structure. }\end{array}$ & $\begin{array}{l}\text { China's hotel industry viz, } \\
\text { product design \& investment } \\
\text { preference, multi-business \& } \\
\text { multi-channel, digital \& } \\
\text { intelligent transformation, and } \\
\text { market reshuffle will be } \\
\text { affected. }\end{array}$ \\
\hline 7. & $\begin{array}{l}\text { Higgins- } \\
\text { Desbiolles (2020) }\end{array}$ & NA & $\begin{array}{l}\text { The critical impact } \\
\text { of COVID-19 on the } \\
\text { tourism industry has } \\
\text { been analyzed. }\end{array}$ & $\begin{array}{l}\text { This worldwide emergency } \\
\text { has led the travel industry } \\
\text { to shut down in various } \\
\text { parts of the world, which } \\
\text { made the concerned }\end{array}$ & $\begin{array}{l}\text { The COVID- } 19 \text { pandemic crisis } \\
\text { has offered a critical } \\
\text { opportunity to re-examine the } \\
\text { travel industry toward an } \\
\text { unrivalled pathway. }\end{array}$ \\
\hline
\end{tabular}


Assessing the Impact of Corona Virus (Covid-19) on Tourism and Hospitality Industry in India A Perspective Study

\begin{tabular}{|c|c|c|c|c|c|}
\hline & & & & $\begin{array}{l}\text { authorities uncover the } \\
\text { probable results. }\end{array}$ & \\
\hline 8. & $\begin{array}{l}\text { Jiang \& Wen } \\
(2020)\end{array}$ & NA & $\begin{array}{l}\text { The impact of } \\
\text { COVID-19 on hotel } \\
\text { marketing and } \\
\text { management } \\
\text { practices has been } \\
\text { discussed. }\end{array}$ & $\begin{array}{l}\text { A three-dimensional } \\
\text { research agenda viz, } \\
\text { artificial intelligence (AI) } \\
\& \text { robotics, hygiene \& } \\
\text { cleanliness, and health \& } \\
\text { health care has been } \\
\text { presented. }\end{array}$ & $\begin{array}{l}\text { An in-depth analysis of the } \\
\text { association between the } \\
\text { healthcare and hotel sector has } \\
\text { been done. Second, the } \\
\text { antecedents of hotel hygiene } \\
\text { and cleanliness are presented to } \\
\text { investigate tourists' perceptions } \\
\text { of the cleanliness of specific } \\
\text { hotel surfaces. }\end{array}$ \\
\hline 9. & Karim (2020) & Malaysia & $\begin{array}{l}\text { This study has been } \\
\text { undertaken to look } \\
\text { at the future effects } \\
\text { of COVID-19 on the } \\
\text { Malaysian travel } \\
\text { industry. }\end{array}$ & $\begin{array}{l}\text { The Malaysian } \\
\text { administration has } \\
\text { constrained the Movement } \\
\text { Control Order (MCO) for } \\
\text { preventing the spread of } \\
\text { the coronavirus. }\end{array}$ & $\begin{array}{l}\text { It has been suggested that } \\
\text { tourism authorities should take } \\
\text { safety measures and the best } \\
\text { approaches in the future. }\end{array}$ \\
\hline 10. & Kaushik (2020) & India & $\begin{array}{l}\text { The global } \\
\text { epidemiology, } \\
\text { treatment, and } \\
\text { control of COVID- } \\
19 \text { have been the } \\
\text { focus of this study. }\end{array}$ & $\begin{array}{l}\text { A public health emergency } \\
\text { has become a national and } \\
\text { international concern as the } \\
\text { virus has spread to more } \\
\text { than } 210 \text { countries around } \\
\text { the world. }\end{array}$ & $\begin{array}{l}\text { The health system, psychology } \\
\text { of people, and economy has } \\
\text { been influenced by the outbreak } \\
\text { of the coronavirus in India. }\end{array}$ \\
\hline 11. & $\begin{array}{l}\text { Kumar } \\
\text { et al. }(2020)\end{array}$ & India & $\begin{array}{l}\text { The strategies have } \\
\text { been suggested to } \\
\text { control the } \\
\text { transmission of } \\
\text { severe acute } \\
\text { respiratory } \\
\text { syndrome } \\
\text { coronavirus in India. }\end{array}$ & $\begin{array}{l}\text { Control strategies such as } \\
\text { quantitative analysis, } \\
\text { computational modelling, } \\
\text { and statistical tools have } \\
\text { been suggested to control } \\
\text { the spread of this virus. }\end{array}$ & $\begin{array}{l}\text { People are cautious about } \\
\text { engaging in business in the } \\
\text { affected area. Therefore, the } \\
\text { pandemic has hindered the } \\
\text { operations of industrial sectors } \\
\text { in India. }\end{array}$ \\
\hline 12. & Kumar, V. (2020) & India & $\begin{array}{l}\text { The objective of this } \\
\text { study has been to } \\
\text { focus on the issues } \\
\text { of COVID-19 and } \\
\text { its impact on the } \\
\text { tourism and hotel } \\
\text { industry in India. }\end{array}$ & $\begin{array}{l}\text { Hotel and airline bookings } \\
\text { have been extremely } \\
\text { affected and reduced due to } \\
\text { COVID-19. Furthermore, it } \\
\text { has resulted in event } \\
\text { cancellations and the loss } \\
\text { of a job as a cost-cutting } \\
\text { measure. }\end{array}$ & $\begin{array}{l}\text { For the upliftment of the travel } \\
\text { industry, the government has to } \\
\text { intervene to beat the current } \\
\text { circumstances by providing } \\
\text { financial aid to this industry. }\end{array}$ \\
\hline 13. & Nepal (2020) & Nepal & $\begin{array}{l}\text { The probable } \\
\text { situation of the } \\
\text { travel and tourism } \\
\text { industry after the } \\
\text { coronavirus } \\
\text { pandemic has been } \\
\text { studied. }\end{array}$ & $\begin{array}{l}\text { The promotion of } \\
\text { adventure tourism would } \\
\text { bring the collapsed } \\
\text { economy of the countries } \\
\text { to its normal. }\end{array}$ & $\begin{array}{l}\text { Various opportunities have } \\
\text { been discussed that post- } \\
\text { COVID-19 will offer to the } \\
\text { tourism business, such as } \\
\text { connecting the gap between the } \\
\text { fundamentals of the UNWTO, } \\
\text { i.e. sustainability and growth } \\
\text { expansion. }\end{array}$ \\
\hline 14. & Nicola (2020) & NA & $\begin{array}{l}\text { The socio-economic } \\
\text { impact of COVID- } \\
19 \text { on the worldwide } \\
\text { economy has been } \\
\text { the focus of this } \\
\text { study. }\end{array}$ & $\begin{array}{l}\text { The pandemic led to social } \\
\text { distancing \& travel } \\
\text { restrictions that have } \\
\text { affected economic sectors } \\
\text { globally. As a result, there } \\
\text { has been a reduction in the } \\
\text { workforce and the loss of } \\
\text { millions of jobs. }\end{array}$ & $\begin{array}{l}\text { Travel restrictions and social } \\
\text { distancing have had an impact } \\
\text { on various sectors of the } \\
\text { country, raising concerns about } \\
\text { a possible recession and job } \\
\text { loss. }\end{array}$ \\
\hline 15. & $\begin{array}{l}\text { Niewiadomski } \\
(2020)\end{array}$ & NA & $\begin{array}{l}\text { The procedures of } \\
\text { globalization and } \\
\text { time-space pressure }\end{array}$ & $\begin{array}{l}\text { It has been observed that } \\
\text { the procedures were driven } \\
\text { by the neoliberal plan, }\end{array}$ & $\begin{array}{l}\text { Deglobalization has provided a } \\
\text { unique opportunity for the } \\
\text { travel industry to re-create as }\end{array}$ \\
\hline
\end{tabular}




\begin{tabular}{|l|l|l|l|l|l|}
\hline & & & $\begin{array}{l}\text { have been studied as } \\
\text { a solution to the } \\
\text { problems caused by } \\
\text { COVID-19 in the } \\
\text { travel industry. }\end{array}$ & $\begin{array}{l}\text { which has re-moulded the } \\
\text { world in the last 75 years. }\end{array}$ & $\begin{array}{l}\text { per the statutes of acceptability } \\
\text { and to dispose of different dark } \\
\text { sides of the travel industry's } \\
\text { development. }\end{array}$ \\
\hline 16. & $\begin{array}{l}\text { Ozili \& Arun } \\
(2020)\end{array}$ & NA & $\begin{array}{l}\text { The objective of this } \\
\text { study has been to } \\
\text { address the reasons } \\
\text { behind the } \\
\text { breakdown of the } \\
\text { economy due to the } \\
\text { coronavirus and, } \\
\text { secondly, } \\
\text { to investigate the } \\
\text { impact of social } \\
\text { distancing } \\
\text { approaches on } \\
\text { monetary policy. }\end{array}$ & $\begin{array}{l}\text { It has been found that } \\
\text { social distancing that } \\
\text { incited the shutdown of } \\
\text { corporate workplaces, } \\
\text { monetary markets, and } \\
\text { many organizations. }\end{array}$ & $\begin{array}{l}\text { The study has revealed that } \\
\text { expanding lockdowns, travel } \\
\text { restrictions, and monetary } \\
\text { policy decisions have truly } \\
\text { affected the financial activities } \\
\text { in the country. }\end{array}$ \\
\hline 17. & $\begin{array}{l}\text { The strategies for } \\
\text { the tourism industry } \\
\text { have been explored } \\
\text { to return to the pre- } \\
\text { COVID-19 normal } \\
\text { to thrive in the } \\
\text { future. }\end{array}$ & $\begin{array}{l}\text { Prideaux et al., } \\
\text { (2020) }\end{array}$ & $\begin{array}{l}\text { Narious possibilities to } \\
\text { change from the present } \\
\text { model that favours asset } \\
\text { utilization to the } \\
\text { ecologically beneficial } \\
\text { model. }\end{array}$ & $\begin{array}{l}\text { There has been a need to adopt } \\
\text { new strategies and to see how it } \\
\text { ought to react to the developing } \\
\text { change of the worldwide } \\
\text { economy. }\end{array}$ \\
\hline
\end{tabular}

\subsection{Research Gaps based on the Review of Literature}

Following a critical review of the literature, it has been discovered that the majority of studies had been conducted to investigate the socioeconomic impact of the coronavirus on the tourism and hospitality industry (Nicola, 2020, Dewan, 2020, Kaushik, 2020, Ghosh, 2020, Nepal, 2020). These studies had been focused on examining the probable changes on this industry that could arise due to this pandemic (Dewan, 2020). Many authors have worked to discuss antipandemic strategies and principles to reorient this industry (Hao et al., 2020, Prideaux et al., 2020, Karim, 2020, Kaushik, 2020 and Kumar et al., 2020).

Globally, it has targeted every industry, particularly the tourism and hospitality industry, which has suffered the most as a result of this crisis. The major reasons have been the travel restrictions and the imposition of lockdowns around the world. The cancellation of events and decrease in the rates of hotel bookings has put a halt to this industry (Agarwal, 2020). Consequently, this industry has lost millions of dollars in just a couple of months. In India, the tourism and hospitality industry contribute a good amount to the GDP, but this pandemic has eventually affected the growth rate of the count,ry (Agarwal, 2020). To overcome this loss, several steps have been taken by the Indian tourism and hospitality marketers. Such as to cut the fixed cost, many tourism and hospitality employees have been laid off in India (Nepal, 2020). Therefore, the Indian economy has been hit badly in terms of growth and employment. There has been a fear of economic crisis and recession in the country (Nepal, 2020 and Nicola, 2020). Some authors have done perspective studies to address the fundamental changes that would occur in this industry (Gossling et al., 2020). Additionally, their studies have proposed reclassification strategies to revive this industry (Kumar et al., 2020, Kumar, V., 2020, HigginsDesbiolles, 2020, Prideaux et al., 2020). The authors (Golechha, 2020, Gossling et al., 2020, Ozili \& Arun, 2020, Prideaux et al., 2020) have suggested that government intervention has been critical to bringing a systematic approach to this industry by converting this situation of threat into an opportunity. It has been proposed to reclassify this industry by converting the 
Assessing the Impact of Corona Virus (Covid-19) on Tourism and Hospitality Industry in India A Perspective Study

existing asset utilization model into an ecologically beneficial model in order to respond to the global change (Prideaux et al., 2020).

However, these prior studies have not considered a holistic approach concerning practical issues and challenges faced by the tourism and hospitality employees in different areas of this industry, such as travel and tourism, hospitality, and airlines. Hence, this present study has filled this gap through the interview method, where interview sessions were done with tourism operators, hotel managers, hotel staff, and airline employees to explore critical information in the form of issues, challenges, and suggestions faced by them while dealing with and serving their customers. Therefore, this present study has considered the feedback provided by the tourism and hospitality industry employees (tourism operators, hotel managers, and airline employees) and presented a crisis management plan in the form of the COVID model.

\section{PURPOSE AND SCOPE OF THE STUDY}

Taking the relevant literature review into consideration, this paper aims to study the impact of the COVID-19 on the tourism and hospitality industry in India. This industry is one of the biggest industries in India contributing a good amount of Gross Domestic Product (GDP) to the country. But due to the worldwide spread of COVID-19, the travel and hospitality industry has been badly affected.

Therefore, the primary objective behind conducting this perspective study has been to assess coronavirus (COVID-19) impact on India's tourism and hospitality industry. Secondly, it has been studied as to what extent of damage this pandemic has done to different tourism and hospitality industry segments regarding revenue and job losses. Further, there has been a need to put forth fundamental control strategies and a crisis management plan to overcome this situation while considering the issues raised by the tourism and hospitality industry employees.

\section{RESEARCH METHODOLOGY}

Various sources and methods have been used in this present study to assess the impact of coronavirus on the tourism and hospitality industry in India.

\subsection{Sources of Data Collection}

This study is based on a systematic literature review, secondary data, expert opinion surveys, and qualitative methods of in-depth interviews with tourism operators, hotel managers, hotel employees, and airline employees. On the other hand, the secondary data has been collected from various national and international research papers, research articles, e-sources, and published reports by the Ministry of Tourism, Government of India, and Department of Tourism.

\subsection{Methods}

The expert opinion has been taken from academicians and researchers related to the tourism and hospitality areas. Further, key questions were decided with their help to explore critical issues and challenges faced by tourism and hospitality employees while carrying their business and dealing with guests. These fundamental questions were further asked in the interviews to get in-depth information. This qualitative method helped identify critical issues, challenges, and strategies used to survive and attract customers. The qualitative method has helped to approach issues more profoundly that had not to be possible through quantitative methods. Later, the content analysis of this information has been done to analyze this oral information.

During the interview session, tourism and hospitality employees were free to talk about their experiences with tourists in this time of crisis, their perspectives, or any problems or 
challenges they encounter in their daily lives while serving their customers. Also, they were asked to address any new ideas that should be implemented to assure safety to guests to regain their trust. Further, they were asked what strategies they used to attract customers.

While interviewing tourism operators, it was observed that there had been a decrease in the number of tourists during some peak seasons of traveling. Tourists prefer to make bookings through online modes and, further, avoid traveling in groups. On the other hand, airline staff mentioned a decline in the number of passengers in the planes. Passengers have been concerned about the standard operating procedures followed at the airport and in planes. Further, one of the hotel managers mentioned that people are afraid to take leisure trips, and most customers visit to make business trips. Additionally, people's length of stay at hotels has also been reduced to 1- 3 days. People have become very much concerned about the hygiene of the hotel rooms and especially food prepared at the hotel.

Other key issues emerged in the interview sessions: financial burden of fixed cost, recurring expenses such as staff salaries, electricity bills, EMI's of loans, advertisement charges, training of staff, installation of new types of equipment (sanitization equipment, facemasks, sanitization chemical). Such expenses have been adding to the cost of operating, which cannot be ignored to continue the business. This information helped to uncover the essential and potential challenges of the tourism and hospitality industry. Therefore, it was necessary to consider secondary data of actual and prospective job loss figures, unemployment rate, and revenue loss of this industry. The collaboration of literature review, secondary data, expert opinion surveys, and interviews has done justice to this study to understand the overall impact of the coronavirus on this industry.

\section{OBSERVATIONS}

\subsection{Impact of Covid-19 on Different Segments of Tourism and Hospitality Industry in India}

\subsubsection{Impact of COVID-19 on the Indian Travel and Tourism Industry}

The Indian travel and tourism industry has been one of the fastest developing segments of the country. Every year, India attracts millions of international tourists from different parts of the world (Dash, 2020 \& Karim et al., 2020). The World Travel and Tourism Council (WTTC) reported that Indian tourism has generated 16.91 lakh crores (US \$240 billion) in 2018, which is $9.2 \%$ of India's Gross Domestic Product (GDP), and provided 42.673 million jobs to the people, which is $8 \%$ of all occupations in the country (Sheikh \& Rabin, 2020).

Until 2019, the Indian tourism industry had been expanding rapidly. Gradually, the situation changed due to the spread of Covid-19 across the world. Approximately 200 countries imposed travel restrictions in their respective countries to limit people entering their borders during peak travel seasons (Lee, 2020).

These travel restrictions have badly affected tourists all around the world. The Indian Associations of Tour Operators (IATO) estimated a combined loss of 85 billion for the travel, hotel, and aviation sector due to travel restrictions (Ray, 2020). In March and April 2020, the tourism industry incurred a loss of 15,000 crores (US \$2.1 billion) (Bajpai et al., 2020). Therefore, the tourism industry has suffered a huge loss in terms of poor revenue generation.

The travel and tourism sector, a source of direct and indirect employment for millions of people, offers $12.75 \%$ of total employment, where $5.56 \%$ and $7.19 \%$ amount to a direct and indirect source (Gossling, 2020). But under this pandemic, 75 million jobs in this industry have been at risk globally, as per the reports of WTTC (Mallapur, 2020). Out of which, nine million jobs in India were at risk (Yu \& Aviso, 2020). 
Assessing the Impact of Corona Virus (Covid-19) on Tourism and Hospitality Industry in India A Perspective Study

As a result, COVID-19 came as bad news for both international and domestic travel and tourism (Strielkowski, 2020). To revive this industry in India, the government must make efforts and initiatives such as digital transformation of this industry (Ozili \& Arun, 2020).

\subsubsection{Impact of COVID-19 on the Hospitality Industry in India}

The hospitality industry in India has been one of the largest hospitality industries in the world, with two thousand hotels and thousands of restaurants registered under the Federation of Hotel Restaurant Association of India (FHRAI) (Hasanat, 2020). But due to COVID-19, the setback faced by the tourism industry adversely affected the hotel industry in India. Numerous cancellations in hotel reservations led to a loss of revenue to the country (Nicola, 2020). As a cost-cutting strategy, a similar effect has been seen on the jobs of millions of people (Nepal, 2020 \& Higgins-Desbiolles, 2020). In India, the hospitality sector may lose 5-7 million jobs by the end of 2020 (Philip, 2020). According to Smith Travel Research (STR), the hotel industry has been severely impacted by a drop in global travel rates (Maker, 2020 and Jiang \& Wen, 2020). Major hotel chains in India announced layoffs and reduced the wages of their employees to overcome this loss. For example, the Marriott and Hilton chain of hotels furloughed many of its employees (Lee, 2020). Expedia, an online travelling platform, cut 3000 jobs in February, while a travel site Booking Holdings put a freeze on hiring employees (Lee, 2020 \& Radhakrishnan, 2020). The hospitality sector has seen a transient fall in job creation due to the outbreak of COVID-19 in the country.

There have been two major problems faced by the Indian hospitality industry:

\section{Drop in the hotel occupancy rates}

This pandemic had a negative impact on hotel occupancy rates, dropping them to $20-40 \%$. This was 2-4 times more effective than the hotel industry had seen during the financial crisis in 2008 (Hao et al., 2020 and Chaturvedi, 2020). Similarly, revenue per available room fell by $65-70 \%$ for four-star or higher category hotels and 50-60\% for two-star hotels. Therefore, the hotel industry confronted difficulties in paying off its debt (Hao et al., 2020). If the hotel occupancy rates of the global financial crisis are taken as a benchmark, the effect of the COVID-19 seems to be the largest.

\section{Loss of jobs of employees}

COVID-19 halted travel, resulting in the loss of more than 100 million jobs by 2020 (Nicola, 2020). As per the reports of the Indian Hotel and Restaurant Association (AHAR), this industry will face a further $15 \%$ loss of jobs in 2021 due to no immediate increase in demand in this industry (Mallapur, 2020).

The hospitality industry in India is still a developing industry. The unorganized segment of this sector has already been closed in the country. Therefore, Indian stakeholders have to take necessary steps to handle the situation.

\subsubsection{Impact of COVID-19 on Indian Airlines Industry}

The United Nations World Trade Organization (UNWTO) reported that restrictions have become more stringent with the increase of coronavirus cases in the world (Higgins-Desbiolles, 2020 and Philip, 2020). As a precautionary measure, the Indian government restricted international flights to land in India beginning March 22 and suspended all domestic flights beginning March 25 (Prideaux, 2020). These flight cancellations have cost the country millions of dollars in tourism because grounded flights have resulted in losses for Indian airlines and the layoff of many airline employees. 
The International Air Transport Association (IATA) has reported a descent of \$314 billion globally in the revenue of passengers, which means a drop of 55\% in figures from 2019 to 2020 (Maker, 2020). Similarly, the Chief Executive and Director-general of the International Air Transport Association (IATA) had mentioned in a report that airlines had experienced a decrease of 47 percent in passenger demand by September 2020, which reduced the revenue by $\$ 11$ billion. To keep up a strategic distance from any bottlenecks, the Indian government had to invest in building infrastructure in the aviation sector since 3 million jobs were at risk.

The aviation industry may take a couple of years to recover; certainly, it's going to be very slow. Though some domestic recovery can be seen in a year, recovery at the international level would take a few more years.

Undoubtedly, the re-opening of air travel will follow a phased approach. It will take a long effort for the aviation industry to return to its normal levels. Outbound travel may be impacted, and it is expected that people will take leisure trips within the country, as domestic travel will help this industry generate revenue for India (Philip, 2020).

\subsection{Unlock Guidelines for Tourism and Hospitality Industry (PHASE 1.0 - 6.0)}

The unlocking phase has started in the country to offer ease to different sectors, which has gone for quite a while. The unlock phase (1.0-6.0) has been studied to see how it has aided the tourism and hospitality industries.

\subsubsection{UNLOCK 1.0 (June 01-June 30, 2020)}

Under unlock 1.0, hotels, restaurants, and shopping malls had been permitted to open with a visitor capacity of $50 \%$. Only asymptomatic cases were allowed to enter, and visitors had to download the 'Aarogya Setu' app for their safety (Jain, 2020). Thermal screenings and sanitation facilities were provided at the entrance of hotels and restaurants. The guests while visiting a hotel had to provide their travel history along with their ID and a self-declaration form at the reception of the hotel (Mukherjee, 2020). Inside public places, social distancing norms were enforced, and special markings were made to maintain a minimum distance of $6 \mathrm{ft}$. These relaxations were prominent for this industry after two months of the coronavirus-induced lockdown.

\subsubsection{UNLOCK 2.0 (July 01-July 31, 2020)}

With the commencement of the second phase of unlocking effective from July 1, 2020, interstate and intrastate movement restrictions were removed. A few states had to open borders for tourists as their economy largely depends on tourism. These states were Himachal Pradesh, Uttarakhand, Goa, and Madhya Pradesh. People coming to these states have to follow a few guidelines and standard operating procedures (SOPs) given by the health and revenue department of the state (Ghosh, 2020). The inter-state movement of the tourists was monitored through their registration in the COVID e-pass software.

\subsubsection{UNLOCK 3.0 (August 01-August 31)}

Beginning August 1, 2020, the Federation of Indian Chambers of Commerce and Industry (FICCI) relaxed restrictions on this industry in India (Khanna, 2020). Now, people were allowed to work in a foreign country following health protocols issued by MoHFW and after accepting the COVID negative certificate issued by the country of origin (Kumar, 2020).

Unlocking 3.0 had been a crucial as international trade had started in India. 
Assessing the Impact of Corona Virus (Covid-19) on Tourism and Hospitality Industry in India A Perspective Study

\subsubsection{UNLOCK 4.0 (September 01-September 30)}

With unlocking 4.0, a few more states, namely Tamil Nadu and Andhra Pradesh, were added to the list of states that have lifted the ban on travel restrictions. The tourists had to enrol for an e-pass with the state government (Tiwary, 2020). The tourists were tested for coronavirus on the spot and quarantined until the results (Thakur, 2020). This was a good step for this industry as tourism activities were resumed in many states.

\subsubsection{UNLOCK 5.0 (October 01-October 31)}

Unlock 5.0, which went into effect on October 1, 2020, provided additional relief to this industry. New recreational activities were introduced to various tourist places by some states to attract tourists, such as nature awareness camps, boating, water sports, etc. (Rana, 2020). The states like Sikkim permitted hotels and other tourism-related services. Kerala and Odisha governments lifted a ban on the tourism sector too (Khanna, 2020). The Uttarakhand government lifted coronavirus restrictions for tourists. The Maharashtra government permitted dine-in facilities in the hotels.

As a result, unlocking 5.0 boosted the country's tourism and hospitality industries. People were travelling for business and pleasure, and hotels were normally open during this new phase of the coronavirus.

\subsubsection{UNLOCK 6.0 (November 01-November 30)}

The Centre gave no new directions in its unlock 6.0 guidelines. However, certain activities were permitted for hotels, restaurants, and the hospitality industry to continue following SOPs.

Undoubtedly, the unlocking phase has started some tourism activities in the country. Yet, some strategies are needed to accelerate this process.

\subsection{Control Strategies to Overcome the Effect of Coronavirus on Tourism and Hospitality Industry in India}

People have been skeptical about their health, safety, and sanitation conditions. As a result, the Indian government has to intervene to resolve this crisis. Further, after considering the primary challenges faced by the hoteliers addressed during interview rounds, some control strategies have been given:

- The major concern for travellers has been about their safety at destinations and hotels. A 'No Touch' policy needs to be implemented in hotels and restaurants to avoid the physical touch. The use of automated systems and robots can help to sanitize hotels and serve food to the customers.

- The government should focus on promoting 'Domestic Tourism' until all restrictions on international travel and tourism are lifted and tourists' safety is ensured.

- The tourism and hospitality industry necessitate organizational restructuring, rightsizing, and downsizing.

- The government should take action to provide relief to this industry in other ways, such as:

- To provide soft loans and working capital at affordable interest rates

○ Waiver of all kinds of license fees

- Allow credit payment on the purchase of goods and services

- To provide food grains at subsidized prices to hotels and restaurants

- A tax holiday for12 months to support the jobs of the employees 
- Permit employees to withdraw partly from their provident fund accounts

- Freeze on EMI

- Delay of GST payments

- Despite the lifting of the lockdown, employee training can continue to be done online. Such programs will assist them in improving their skills and introducing new changes.

\section{DISCUSSION}

Following a critical analysis of the prior studies related to tourism and hospitality, it has been discovered that a large number of studies have been conducted to ascertain the short and longterm influence of the coronavirus's on this industry. Several studies have addressed structural changes in this industry and suggested reorganisation and anti-pandemic strategies to recover this industry. These studies have enabled a systemic approach to this industry by shifting this vulnerability into an opportunity. Therefore, it has been suggested to reorganise this industry completely, where old technology be replaced with automated and digital systems. These systems should be organised considering the employees' needs and interests, which do not completely replace the staff but used as a complementary to some extent. It will help solve unemployment and layoffs that have been the major issues in this current situation. Therefore, the tourism and hospitality marketers should understand the tourists' and employees' issues and adjust things accordingly.

A profound analysis of coronavirus's impact on the tourism and hospitality industry has been done in the present study. Additionally, suggestions received from tourism and hospitality employees in the interview sessions have helped to analyse the practical issues while serving their customers. Hence, an initiative has been taken to cover different areas such as travel and tourism, hospitality, and airlines in this study. The impact has been studied through secondary data and interview methods, which has helped find better solutions to the existing challenges of this industry. Further, the unlocking phase has also been studied and control strategies have been addressed that the government and tourism marketers should implement. The COVID model has been presented as managerial implications to provide an overall solution to this crisis.

Hence, this present study has covered coronavirus's impact on the tourism and hospitality industry from all spheres with possible solutions.

\section{MANAGERIAL IMPLICATIONS}

This paper has presented significant implications for tourism and hospitality marketers' after a thorough analysis of the coronavirus's impact on this industry. Tourism and hospitality marketers should follow specific survival strategies such as Cost-cutting, Orderliness, Virtualization, Integration, and Domestication (COVID). These survival strategies constitute the COVID model.

Cost-cutting- Hotel managers should set out cost-cutting as a foremost strategy to reduce losses in this industry. The managers should identify non-essential services, which are low in demand to shut down to minimize their utility bills, such as elevators, escalators, and closing down some guest room floors and restaurants. Further, labour costs can also be reduced through negotiating salary reductions, initiating leave without pay, and laying off temporary employees.

Orderliness - It stands for health, safety, sanitation, and operational techniques. Now, safety of tourists has become foremost important for hoteliers. Orderliness constitutes two approaches, i.e., the software approach and the hardware approach. The software approach means that the hotel staff is trained to ensure sanitation protocols for the hotel guests. Such as maintaining social distance protocols, using disposable materials, frequent cleaning of surfaces, wearing 
Assessing the Impact of Corona Virus (Covid-19) on Tourism and Hospitality Industry in India A Perspective Study

PPEs by staff and guests. On the other hand, the hardware approach means hygiene equipment in the hotels, such as sanitizers, chemical sterilizers, and air filters.

Virtualization - Through information and communications technology (ICT) in hotels, virtualization can maintain social distance between people. ICT has enabled hotel managers to have virtual meetings with their staff through various apps such as Zoom, Google Meet and GoToMeeting, which has facilitated videoconferencing. Such digital systems will be beneficial for hoteliers as this technology will replace the staff and minimize human contact.

Integration - Integration means all hotels should unify their efforts to find solutions to this crisis. Secondly, the hotels should collaborate to negotiate technical and financial assistance with the government.

Domestication - To survive this crisis, the hotel should develop innovative promotional packages for local tourists to bring them to the tourist places. Hotels should offer 'Quarantine Packages' to the local people as a marketing strategy. Further, hotels can collaborate with the government to serve as isolation centres.

\section{RESEARCH CONTRIBUTION/IMPLICATIONS}

This paper has studied the impact of coronavirus on the tourism and hospitality industry in detail. Different sectors associated with this industry, such as travel and tourism, hospitality, and airlines, have also been covered. Secondly, interview sessions conducted with the tourism and hospitality employees have highlighted practical issues. Suggestions have been taken from them in the form of feedback that has been presented in the COVID model.

\section{LIMITING FACTORS AND SCOPE FOR FUTURE RESEARCH}

This study's limitations have been mentioned below, along with the scope for future research.

- This is a perspective study with limited scope. Hence, in future, an exploratory study can be done with the survey method. The tourists can be interviewed and asked to fill questionnaires, which can help determine the impact of COVID-19 on their trip planning behaviour. Such studies will add to the tourism and hospitality academic area.

- The focus of this study has been the tourism and hospitality industry alone. As a result, future research can be done in other sectors such as retail, healthcare, banking, education, political parties, the film industry, etc.

- Comparative studies could be conducted, where the impact of COVID-19 on this industry in developing countries can be compared with the developed countries. This can help understand the challenges faced by this industry in developing nations in contrast to developed nations. Likewise, marketing strategies can be made.

\section{CONCLUSION}

Outbound travel and inbound travel in India have suffered a lot during this pandemic. The coronavirus has had a significant economic impact on the tourism and hospitality industry. To handle the current situation, the government of India has taken many precautionary measures. The regular travel pattern will take a couple of years to bounce back. It is right to state that the coronavirus has changed the entire pattern of this industry.

Lastly, financial and economic losses can be recovered in a couple of years, but people's lives are very precious, which can't be recovered. The safety of the people is of the foremost importance in this COVID-19 phase. As a result, India's people should follow the government's safety measures and support social distancing to avoid health hazards such as those seen in the aftermath of this pandemic. 


\section{REFERENCES}

[1] Agarwal, N. (2020). Unlock 5: Places of worship, cinema halls to remain closed in odisha till October 31. https://zeenews.india.com/india/unlock-5-places-of-worship cinema-halls-toremain-closed-in-odisha-till-october-31-2314048.html.

[2] Bajpai, P., Khan, I., \& Sitharaman, G. (2020). What the corona outbreak is doing to India's already suffering economy. Youth Ki Awaaz. https://www.youthkiawaaz.com/2020/04/coronaoutbreaks-impact-on-indian-economy.

[3] Bhattacharya, A., \& Mathew, P. (2019). India's GDP growth slumps to a shocking $4.5 \%$ in September quarter. QuartzIndia. https://qz.com/india/1758454/indias-gdp-falls-below-5percent/.

[4] Chaturvedi, A. (2020). Despite curbs being eased, recovery for India's hospitality sector looks dismal and bleak. The Economic Times.

https://economictimes.indiatimes.com/industry/services/hotels-/-restaurants/despite-curbsbeing-eased-recovery-for-indias-Hospitality-sector-looks-dismal-and-

bleak/articleshow/76644969.cms?from=mdr.

[5] Chaturvedi, A. (2020). Tourism ministry extends validity period of approval/classification of hotels, accommodation units till June 30. The Economic Times.https://economictimes.indiatimes.com/industry/services/hotels-/-restaurants/Tourismministry-extends-validity-period-of-approval/classification-of-hotels-accommodation-unitstill-june-30/articleshow/75998291.cms?from=mdr.

[6] Dash, J. (2020). Covid-19 Impact: Tourism industry to incur Rs 1.25 trn revenue loss in 2020. https://www.business-standard.com/article/economy-policy/covid-19-impact-Tourismindustry-to-incur-rs-1-25-trn-revenue-loss-in-2020-120042801287_1.html.

[7] Dewan, M. (2020). Solutions for surviving COVID-19: A Malaysian hotel and tourism industry perspective. ResearchGate.

https://www.researchgate.net/publication/341203575_Solutions_for_Surviving_COVID19_A_Malaysian_Hotel_and_Tourism_Industry_Perspective.

[8] Ghosh, A. (2020). Tourism surviving strategy: Indian perspective during Covid-19 Pandemic.https://www.researchgate.net/publication/343794815_Tourism_Surviving_Strategy _Indian_Perspective_during_Covid-19_Pandemic.

[9] Ghosh, M. (2020). Airlines to witness $47 \%$ decline in passengers in 2020 due to the Covid -19 pandemic. Www.livemint.com. https://www.livemint.com/companies/news/airlines-towitness-47-decline-in-passengers-in-2020-due-to-the-covid-19-pandemic11590762864028.html.

[10] Ghosh, P. (2020). Unlock 2.0: These Indian states are now open to tourists: checklist, date, conditions (But stay home). https://www.india.com/news/india/unlock-2-0-these-indian-statesare-now-open-to-tourists-check-list-date-conditions-but-stay-at-home-4075176/.

[11] Golechha, M. (2020). COVID-19, India, lockdown and psychosocial challenges: What next? https://journals.sagepub.com/doi/full/10.1177/0020764020935922.

[12] Gossling, S., Scott, D., \& Hall, C. M. (2020). Pandemics, tourism and global change: a rapid assessment of COVID-19. Journal of Sustainable Tourism, 1-20. https://doi.org/10.1080/09669582.2020.1758708

[13] Hao, F., Xiao, Q., \& Chon, K. (2020). COVID-19 and China's hotel industry: Impacts, a disaster management framework, and post-pandemic agenda. International Journal of Hospitality Management.

https://www.sciencedirect.com/science/article/pii/S0278431920301882?via=ihub. 
Assessing the Impact of Corona Virus (Covid-19) on Tourism and Hospitality Industry in India A Perspective Study

[14] Haq, Z. (2020). India stares at a long road to economic revival. Hindustan Times. https://www.hindustantimes.com/india-news/india-stares-at-a-long-road-to-economicrevival/story-SBgOdlnTkVJ1eOIZbVM1yN.html.

[15] Hasanat, Mohammad Waliul, Hoque, Ashikul, Afrin, Farzana, \& Anwar, Mashrekha. (2020). The Impact of coronavirus (COVID-19) on e-Business in Malaysia. Asian Journal of Multidisciplinary Studies, 3(1).

[16] Higgins-Desbiolles, F. (2020). Socializing tourism for social and ecological justice after COVID-19.TourismGeographies, 114.https://doi.org/10.1080/14616688.2020.1757748

[17] Jain, A. (2020). Unlock-1: Health Ministry guidelines and SOPs for offices, malls, religious places. The Week. https://www.theweek.in/news/india/2020/06/04/unlock-1-health-ministryguidelines-and-sop-for-offices-malls-restaurants.html.

[18] Jiang, Y., \& Wen, J. (2020). Effects of COVID-19 on hotel marketing and management: a perspective article. International Journal of Contemporary Hospitality Management. https://www.emerald.com/insight/content/doi/10.1108/IJCHM-03-2020-0237/full/html.

[19] Karim, W., Haque, A., Anis, Z., \& Ulfy, M. A. (2020). The movement control order (MCO) for COVID-19 crisis and its impact on tourism and hospitality industry in Malaysia. International Tourism and Hospitality Journal. https://doi.org/10.37227/ithj-2020-02-09.

[20] Kaushik, S., Kaushik, S., Sharma, Y., Kumar, R., \& Yadav, J. P. (2020). The Indian perspective of COVID-19 outbreak. https://link.springer.com/article/10.1007/s13337-020-00587-x.

[21] Khanna, P. (2020). Unlock 3.0 guidelines: Here is what's allowed, what's not. The Indian Express. https://indianexpress.com/article/india/unlock-3-0-guidelines-rules-whats-allowedwhats-not-6529596/.

[22] Khanna, P. (2020). Unlock 5.0 guidelines October 2020: More relaxations expected from tomorrow. The Indian Express. https://indianexpress.com/article/india/unlock-5-guidelinesoctober-relaxations-lockdown-6618119/.

[23] Kumar, C. (2020). IMF's projection of $1.9 \%$ GDP growth for India highest in G-20, says RBI Governor Das. Business Today. https://www.businesstoday.in/current/economy-politics/imfprojection-19-gdp-growth-for-india-highest-in-g20-rbi-governor-das/story/401295.html.

[24] Kumar, C. (2020). Coronavirus impact: CII pegs India's GDP growth between-0.9\% to $1.5 \%$ for FY21. Business Today. https://www.businesstoday.in/current/economy-politics/coronavirusimpact-cii-pegs-india-gdp-growth-between--09-to-15-for-fy21/story/401812.html.

[25] Kumar, M. (2020). Unlock 3.0: What is allowed, what is not; check details. The Financial Express. https://www.financialexpress.com/lifestyle/health/unlock-3-0-guidelines-what-isallowed-what-is-not/2039126/.

[26] Kumar, U., S., Kumar, T., D., Christopher, P., B., \& Doss, G. P., C. (2020). The Rise and Impact of COVID-19 in India. https://www.frontiersin.org/articles/10.3389/fmed.2020.00250/full.

[27] Kumar, V. (2020). Indian tourism industry and COVID-19: Present scenario. Journal of Tourism and Hospitality Education, 10, 179-185. https://doi.org/10.3126/jthe.v10i0.28768.

[28] Lee, Yen Nee. 5 Charts show which travel sectors were worst hit by the coronavirus. (2020). www.cnbc.com/2020/05/06/coronavirus-pandemics-impact-on-travel-Tourism-in-5charts.html.

[29] Maker, A. (2020). Potential impact of Covid-19 on Indian aviation and tourism. Business Traveler. https://www.businesstraveller.com/businesstravel/2020/04/06/potential-impact-ofcovid-19-on-Indian-aviation-and-Tourism/. 
[30] Mallapur, C. (2020). Job loss looms over millions as COVID-19 brings tourism to a standstill |. IndiaSpend. https://www.indiaspend.com/job-loss-looms-over-millions-as-covid-19-bringsTourism-to-a-standstill/.

[31] Mallapur, C. (2020). India's Covid-19 lockdown may cause 38 million job losses in the travel and tourism industry. Scroll.in. https://scroll.in/article/959045/indias-covid-19-lockdown-maycause-38-million-job-losses-in-the-travel-and-Tourism-industry.

[32] MoHFW| Home. www.mohfw.gov.in. (2020). https://www.mohfw.gov.in/index.html.

[33] Mukherjee, K. (2020). A comparative analysis of the lockdown and unlock policies on the COVID-19 situation in India. https://doi.org/10.33774/coe-2020-fdqtr.

[34] Mukherji, B. (2020). Coronavirus impact: Indian industry seeks relief measures to aid the economy. Livemint. https://www.livemint.com/companies/news/coronavirus-impact-indianindustry-seeks-relief-measures-to-aid-economy-11584904435575.html.

[35] Nepal, S. K. (2020). Travel and Tourism after COVID-19 - business as usual or opportunity to reset? Tourism Geographies, 1-5. https://doi.org/10.1080/14616688.2020.1760926.

[36] Nicola, M., Alsafi, Z., Sohrabi, C., Kerwan, A., Al-Jabir, A., Iosifidis, C., Agha, R. (2020). The socio-economic implications of the coronavirus pandemic (COVID-19): A review. International Journal of Surgery, 78, 185-193. https://doi.org/10.1016/j.ijsu.2020.04.018.

[37] Niewiadomski, P. (2020). COVID-19: From temporary de-globalization to a re-discovery of Tourism? Tourism Geographies, 1-6. https://doi.org/10.1080/14616688.2020.1757749.

[38] Ozili, P. K., \& Arun, T. (2020). Spillover of COVID-19: Impact on the global economy. SSRN Electronic Journal. https://doi.org/10.2139/ssrn.3562570.

[39] Philip, L. (2020). Hotel industry might take 6 to 9 months to recover fully: Puneet Chhatwal, $\mathrm{MD}$ and CEO, Indian Hotel Company. Economictimes.

https://economictimes.indiatimes.com/industry/services/hotels-/-restaurants/hotel-industrymight-take-6-to-9-months-to-recover-fully-puneet-chhatwal-md-and-ceo-indian-hotelcompany/articleshow/75034595.cms.

[40] Prideaux, B., Thompson, M., \& Pabel, A. (2020). Lessons from COVID-19 can prepare global Tourism for the economic transformation needed to combat climate change. Tourism Geographies, 1-12. https://doi.org/10.1080/14616688.2020.1762117.

[41] Radhakrishnan, A. (2020). COVID-19| Post-Pandemic, India's Tourism Sector Stares at 70\% Job Loss. https://www.thehindu.com/news/national/kerala/coronavirus-Tourism-sector-staresat-70-job-loss/article31310234.ece.

[42] Rajan, R., \& Gopalan, S. (2020). Covid-19: Another blow to India's economy. The Hindu.https://www.thehindubusinessline.com/opinion/covid-19-another-blow-to-indiaseconomy/article31208648.ece.

[43] Rana, Y. (2020). Punjab: Forest department upbeat to attract tourists after Unlock 5.0 guidelines: Chandigarh News - Times of India. The Times of India. https://timesofindia.indiatimes.com/city/chandigarh/punjab-forest-department-upbeat-toattract-tourists-after-unlock-5-0-guidelines/articleshow/78445676.cms.

[44] Ray, M. (2020). India most infected by Covid-19 among Asian countries, Leaves Turkey Behind. https://www.hindustantimes.com/india-news/india-most-infected-by-covid-19-among-asiancountries-leaves-turkey-behind/story-Jjd0AqIsuL3yjMWg29uJ3I.html.

[45] Sanyal, A. (2020). India crosses UK to become fourth worst hit by Coronavirus. NDTV.com.https://www.ndtv.com/india-news/india-crosses-uk-to-become-fourth-worst-hitby-coronavirus-2244769.

[46] Sastry, V.V.L.N. (2019). India's Demonetization: Pros and Cons. https://papers.ssrn.com/sol3/papers.cfm?abstract_id=3314670. 
Assessing the Impact of Corona Virus (Covid-19) on Tourism and Hospitality Industry in India A Perspective Study

[47] Sharma, S. (2020). Covid-19 cases in India exceed 100,000, but low fatality ratio offers hope. https://www.hindustantimes.com/india-news/cases-exceed-100-000-but-low-fatality-ratiooffers-hope/story-WKtH4uhMTXZNfqp3sKxvZP.html.

[48] Sheikh, Knvul, \& Rabin, R. C. (2020). "The Coronavirus: What scientists have learned so far?" Nytimes. https://www.nytimes.com/article/what-is-coronavirus.html.

[49] Strielkowski, W. (2020). International tourism and COVID-19: Recovery strategies for tourism organizations. https://doi.org/10.20944/preprints202003.0445.v1.

[50] Thakur, A. (2020). Traveling in the Times of COVID-19: A Complete Guide if Planning a Trip in the Pandemic. India News, Breaking News, Entertainment News | India.com. https://www.india.com/travel/articles/travelling-in-the-times-of-covid-19-a-complete-guide-ifplanning-a-trip-in-the-pandemic-4152685/.

[51] Tiwary, D. (2020). Unlock 4.0 guidelines: Metro to start September 7, no state lockdowns outside containment zones. The Indian Express. https://indianexpress.com/article/india/indiaunlock-4-0-guidelines-6575245/.

[52] Unctad. Global trade impact of Coronavirus (COVID-19) epidemic. (2020). https://unctad.org/en/pages/MediaAlertDetails.aspx? OriginalVersionID=56.

[53] Unlock 1.0: Centre releases guidelines for opening of hotels/restaurants, malls, and religious places. (2020). The Times of India. https://timesofindia.indiatimes.com/india/unlock-1-0-govtreleases-guidelines-for-opening-of-restaurants-offices-and-religious-

places/articleshow/76201154.cms.

[54] Unlock 3.0: FICCI calls for easing of restrictions on Travel, Tourism, and Hospitality - ET TravelWorld. ETTravelWorld.com. (2020).

https://travel.economictimes.indiatimes.com/news/associations/unlock-3-0-ficci-calls-foreasing-of-restrictions-on-travel-tourism-and-hospitality/77193216.

[55] Vyas, M. (2020). Lockdown 2.0: Unemployment rate hits 26\% in India, 14 crores lose jobs, says CMIE. https://www.nationalheraldindia.com/national/lockdown-20-unemployment-rate-hits26-in-india-14-crore-lose-jobs-says-cmie.

[56] Vyas, M. (2020). Lockdown 2.0: Unemployment rate touches 26\% amid Covid-19 outbreak. Business Standard. https://www.business-standard.com/article/opinion/unemployment-ratetouches-26-per-cent-120042001081_1.html.

[57] World Tourism Organization. UNWTO. https://www.unwto.org/impact-assessment-of-thecovid-19-outbreak-on-international-tourism.

[58] Yu, K. D. S., \& Aviso, K. B. (2020). Modeling the economic impact and ripple effects of disease outbreaks. Process Integration and Optimization for Sustainability, 4(2), 183-186. https://doi.org/10.1007/s41660-020-00113-y. 